UDC 349.6:347.44

DOI:10.5937/RKSPP1901037D

LARRY A. DIMATTEO

\title{
RIGHT TO A CLEAN ENVIRONMENT: ROLE OF CONTRACTS AND CONTRACT LAW
}

This Report analyses the use of contracts and contract law to advance sustainability goals. It discusses the problem of planned obsolesence-the intentional manufacturer of products with shorter lifespans. In the area of contracts, the use and enforceability of contractual sustainability clauses is reviewed. The role of contracts in advancing sustainability is examined at different levels: government-to-government through bilateral investment treaties, public-private contracts (government procurement) and in private green contracts incentivized by government policy and programs. The Report will then offer approaches to combatting the problem of planned obsolesence. It advances the argument that warranty law offers the best and most comprehensive approach to improving product durability.

Key Words: Bilateral Investment Treaties (BITs), circular economy, duty to repair, government procurement, green contract, implied warranty of durability, planned obsolesence, right to self-repair, sustainability, warranty law

Prof. Dr. Larry A. DiMatteo, Huber Hurst Professor of Contract Law \& Legal Studies, Warrington College of Business; Affiliate Professor at the Levin College of Law; Affiliate Professor at the Center for European Studies. He holds degrees of B.A. (economics) \& B.A. Political Science (State University of New York at Buffalo); J.D. Cornell Law School; LL.M. Harvard Law School; Ph.D. Monash University (business \& commercial law). The author would like to thank to Prof. Dr. Jelena S. Perović Vujačić, President of the Kopaonik School of Natural Law for inviting him to participate at the Kopaonik School of Natural Law annual conference. Much of the materials in this report was excerpted from Larry A. DiMatteo, Stefan Wrbka, "Planned Obsolescence and Consumer Protection: The Unregulated Extended Warranty and Service Contract Industry", Cornell Journal of Law \& Public Policy, Vol. 28, 2019; Larry A. DiMatteo, "Sustainability and Contracts", Taxation and Comparative Environmental Regulation within the Framework of the Right to Sustainable Development" (editors. Antonio Cubero, Patricio Masbernat, Thomson Reuters, 2019; Stefan Wrbka, Larry A. DiMatteo, "Comparative Warranty Law: Case of Planned Obsolesence", University of Pennsylvania Journal of Business Law, Vol. 21,2019, e-mail: larry.dimatteo@warrington.ufl.edu 


\section{INTRODUCTION}

Contracts, both-private and public-private-and contract law can play a major role in the sustainability movement. For purposes of the Report, sustainability relates to the reduction of waste in the use and reuse of natural resources in the production of goods and products. This area of sustainability includes both the processes of production and the end products of those processes. In the area of production processes the major issue analyzed is the sustainability of the world supply chains, while the focus of product outcomes will be on the issue of the durability and reuse of products. This Report will concentrate on the later of the two areas-production of durable goods. In sum this Report, will focus on how contracts have been used to advance greater product durability through the minimization of waste. More importantly, this Report will propose ideas as to how contracts and contract law can more effectively be used to improve the efficient use of natural resources through the reduction of waste, re-use of materials, and increased product durability.

Interrelated with the issue of sustainability are the areas such as fairness, justice, human rights, and intellectual property rights. These issues often relate to one another directly and indirectly. For example, something may be sustainable but also cause injustice from a distributive justice perspective when sustainability benefits only a minority of the population. Another example is presented by the intersection between human rights and intellectual property rights. ${ }^{1}$ Often these types of rights are seen in conflict, such as when a company's intellectual property rights prevent medicines or scientific innovation from reaching people most in need. In other ways, the two types of rights can be seen as co-existent or complimentary. In cases, were governments do not recognize or protect the rights of inventors and artists, then such rights can be interpreted as basic human rights. From the perspective of sustainability, innovation is essential to most effective use of resources, by reducing waste and protecting the environment. Failure to recognize intellectual property rights in these areas will limit the development of new means to sustainability. In the end, the protection of intellectual property rights and limits to those protections directly effects basic human rights such as the right to work, right to life, right to education, right to health, and the right to food, along with freedom of thought and freedom of expression as reco-

1 See Peter K. Yu, "Intellectual Property, Human Rights, and Methodological Reflections", Texas A \& M School of Law Research Paper, No. 18-36, 2018, available at https://ssrn.com/abstract $=3247346,8.10 .2018$. 
gnized in the Universal Declaration of Human Rights (UDHR) ${ }^{2}$ and the International Covenant on Economic, Social and Cultural Rights (ICESCR). ${ }^{3}$

Contract law also plays a role in the protection of such rights and in the promotion of justice and fairness, especially in the area of government procurement and public-private ventures. In seeking justice and fairness, public policy as reflected in international conventions and regional initiatives may restrict freedom of contract in order to serve societal goals. For example, European Union law allows restrictions of freedom of establishment and free marketing of services on grounds of public policy, public security and public health. Other public interests that can justify restrictions on freedom of contract include: environmental protection, ${ }^{4}$ keeping an agricultural community in place and combating excessive land speculation, ${ }^{5}$ land-use planning, ${ }^{6}$ consumer protection, ${ }^{7}$ and protection of workers. Thus, communal interests can restrict private parties' freedom to contract, such interests (including justice and fairness), they can also place immutable rules and principles into contract law. In such cases, private parties do not have freedom from contract (unenforceability of certain contract terms; general policing doctrines like the duty of good faith or the doctrine of unconscionability). The Report examines both the freedom of contracting parties to incorporate sustainability factors into their contracts and the law's ability to impose sustainability requirements on private contracts.

\section{USE OF CONTRACTS TO ADVANCE SUSTAINABILITY}

This Part will examine the use and enforceability of contractual sustainability clauses. It also provides examples of the use of public procurement contracts, government-to-government contracts (bilateral investment treaties), and private green contracts to advance sustainability goals.

2 Universal Declaration of Human Rights, G.A. Res. 217 (III) A, U.N. Doc. A/RES/217(III) (Dec. 10, 1948).

3 International Covenant on Economic, Social and Cultural Rights, Dec. 16, 1966, 993 U.N.T.S. 3 (entered into force January 3, 1976).

4 C-400/08 Commission v Spain (prohibition of shopping malls in Catalonia).

5 C-370/05 Festersen, ECLI: EU: C:2007: 59 para. 27.

6 C-213/04 Ewald Burtscher v Josef Stauderer, ECLI: EU: C: 2005: 731 para. 46 (limitations on secondary residences).

7 C-342/14 X-Steuerberatungsgesellschaft, ECLI: EU. 


\section{Enforceability of Sustainability Clauses}

There is an almost endless array of sustainability standards and goals that can be used to construct contractual sustainability clauses. This is an important method to convert soft law standards to enforceable hard law. An analogy can be found in intellectual property protection. Some countries are notorious for failing to enforce intellectual property laws; some of this is due to the lack of expertise in their national court systems. This incentivizes licensors of technology to write extremely one-sided pro-licensor licensing contracts, which includes transplanting protections provided by law into their contracts. The logic being that some national courts may not be able to deal with the nuances of intellectual property law, but they are capable of handling breach of contract litigation. Although damages may be difficult to prove in breaching contractual sustainability clauses, the breach does allow the non-breaching party to terminate the contract and such breaches cause negative reputational effects on the breaching party.

It is important for sustainability clauses to use words of obligations such as the supplier "will," "required to," or "must" and avoid merely referential language (such as, "according to the UN Global Compact"), as well as avoiding aspirational language, such as you should strive to comply. ${ }^{8}$ In the latter case, passive language may be construed as non-enforceable guidance or merely placed in the contract for public relations value. Additionally, the level of vagueness $f$ these types of terms lead most courts to disregard them due to the indefiniteness of the clause. Also, sustainability clauses may be incorporated into the general conditions or standard terms part of a contract. The enforceability of standard term provisions in a contract or terms in other documents incorporated by reference varies among national legal systems. Some courts, especially in the civil law tradition, may be disinclined to recognize such terms as part of the contract. The enforceability of sustainability clauses is dependent on the drafting and the placement of the clauses in the contract. Thus, enforceability increases when the obligations of the other contracting party are highly specified instead of be placed as a simple recital to general principles (incorporation by reference). The placement of the clauses in the body of the contract and not incorporated into general conditions, the use of specifically worded clauses, and the use of words of promise or obligation increase the likelihood of enforceability.

8 Kasey McCall Smith, Andreas Rühmkorf, "From national law to international law: The opportunities and limits of contractual CSR supply chain governance", Law and Responsible Supply Chain Management: Contract and Tort Interplay and Overlap (editors Vibe Ulfbeck, Alexandra Hanhov, Katerina Mitkidis), Routledge, London, 2019, Ch. 2. 


\section{Inter-Government Contracts}

Bilateral Investment Treaties (BITs) establish the terms and conditions for private investment or FDI by nationals and companies of one country in another country. BITs have evolved over the decades from pure investment protection to areas such as human rights, labor rights, environmental protection, and sustainability. ${ }^{9}$ In 2012, the United States published a new Model Bilateral Investment Treaty. The Preamble states that:

Agreeing that a stable framework for investment will maximize effective utilization of economic resources and improve living standards and desiring to achieve these objectives in a manner consistent with the protection of health, safety, and the environment, and the promotion of internationally recognized labor rights. ${ }^{10}$

This provision makes clear that growth and investment for the sake of economic development is to be tempered by concerns with issues of safety and health, environmental harm, and labor rights. ${ }^{11}$ Implicit in protecting the environment is sustainability, which is the minimization of the use of natural resources and the development of means of production that are environmentally friendly. A country that is party to a BIT that is concerned with practices of the other party or a country receiving foreign investment is allowed under the Model BIT to the appointment of "one or more experts to report to it in writing on any factual issue concerning environmental, health, safety, or other scientific matters raised by a disputing party." 12 The investment country receiving parties are also authorized to regulate such investments: "non-discriminatory regulatory actions by a Party that are designed and applied to protect legitimate public welfare objectives, such as public health, safety, and the environment, do not constitute indirect expropriations." 13 Thus, domestic regulations aimed at enhancing sustainability,

9 Larry A. DiMatteo, International Business Law and the Legal Environmental: A Transactional Approach, Routledge Publishing, New York, 2017, 601.

10 U.S. Model Bit (2012), Preamble.

11 The Model Bit defines environmental harm as follows: "[Environmental law are those whose] primary purpose of which is the protection of the environment, or the prevention of a danger to human, animal, or plant life or health, through the: (a) prevention, abatement, or control of the release, discharge, or emission of pollutants or environmental contaminants; (b) control of environmentally hazardous or toxic chemicals, substances, materials, and wastes, and the dissemination of information related thereto; or (c) protection or conservation of wild flora or fauna, including endangered species, their habitat, and specially protected natural areas."

12 Article 32 Expert Reports (Arbitration).

13 Annex B Appropriation, Section (4)(b). 
which are enacted subsequent to the signing of a BIT, would apply to BIT investments. On the other hand, investment-receiving countries are not allowed to decrease environmental protections in order to attract foreign investment. ${ }^{14}$ In sum, BITs are government-to-government contracts that can be modified to advance sustainability goals.

\section{Public-Private Contracts: Government Procurement and Concession Agreements}

Numerous concerns, interests, and objectives need to be balanced in developing a sustainable public procurement policy:15 "'Green procurement' has traditionally been given a greater role within European procurement mechanisms." 16 The 2014 EU Public Procurement Directive ${ }^{17}$ has been used to make the "case for sustainable public procurement linking minimisation of social and environmentalrisk with enhanced organisational image, cost saving (predicated on life-cycle costing methodologies), and the creation of markets for products and services that enrich sustainability." ${ }^{18}$ Public procurement plays a key role in the Europe 2020 strategy as one of the market-based instruments to be used to achieve smart, sustainable and inclusive growth. ${ }^{19}$ The importance of the Directive, as well as soft law standards, to contracts is that they can be used in the drafting of sustainability-friendly contracts. The relevant obligations can be mirrored in contract clauses.

${ }^{14}$ In the area of workers or labor rights, the countries to the BIT obligate themselves to obeying the International Labor Organization's (ILO) Declaration on Fundamental Principles and Rights at Work. Labor rights include the areas of freedom of association; effective recognition of the right to collective bargaining; elimination of all forms of forced labor; effective abolition of child labor; elimination of discrimination in respect to employment; and acceptable conditions of work with respect to minimum wages, hours of work, and occupational safety and health.

15 These competing concerns include: "a range of environmental, economic, and social issues, including social policy concerns over equality and worker rights, ideas about ethical trade and social justice, 'green' product and service areas, and economic aspects related to innovation and supplier diversity". Eleanor Fisher, “The Power of Purchase: Addressing Sustainability through Public Procurement", European Procurement \& Public Private Partnership Law Review, Vol. 2, 2013, p. 3.

16 Ibidem.

17 Directive 2014/24/EU of the European Parliament and of the Council of 26 February 2014 on public procurement (Public Procurement Directive).

18 E. Fisher, p. 2.

19 European Commission, Communication of 3 March 2010, Europe 2020, a strategy for smart, sustainable and inclusive growth. 
Public or government procurement provides the opportunity to experiment with contract terms that promote sustainability goals. One commentator asserts that: "Public procurement is emphasised as a unique opportunity to promote awareness of and respect for human rights and the terms of contracts are described as a tool." ${ }^{20}$ Sustainable public procurement is: "a process whereby organisations meet their needs for goods, services, works and utilities in a way that achieves value for money on a whole life basis in terms of generating benefits not only to the organisation, but also to society and the economy, whilst minimising damage to the environment." ${ }^{21}$ Contract provisions requiring sustainable use of materials need to include additional provisions directed at managing (operationalizing those requirements or obligations), as well as installing a monitoring process to ensure compliance.

A concession agreement is a negotiated contract between a company and a government that gives the company the right to operate a specific business within the government's jurisdiction, subject to certain conditions. For example, a government that is looking to attract mining companies to an impoverished area may offer significant inducements, such as tax breaks and a lower royalty rate. The term concession agreement is used in two slightly different ways in the business world. Both refer to a type of negotiated contract, which gives a company the right to do business, with some specific requirements. In one sense, it refers to a contract between a foreign company and a government in which the government guarantee certain conditions, such as no changes in the income tax rate applicable to the foreign company, in order to attract the foreign company to invest in its country. In a second sense, this type of agreement may include the foreign company (concessionaire) the exclusive right to do business in a particular area or venue in exchange for some carefully negotiated terms. ${ }^{22}$ The government may also insert sustainability clauses into these contracts. The government could provide incentives (lower taxes; lower royalty rights) in return for the company agreeing to follow sustainability methods related to mining, growing, manufacturing, and so forth.

Another area to promote sustainability is the implementation of government policies and programs that incentivize private contractors to make con-

20 Asa Edman, Peter Nohrstedt, "No Socially Responsible Public Procurement without Monitoring the Contract Conditions", European Procurement \& Public Private Partnership Law Review, Vol. 12, 2017, pp. 352, 353.

21 Department of Environment, Food and Rural Affairs, Procuring the Future, Sustainable Procurement National Action Plan: Recommendations from the Sustainable Procurement Task Force, DEFRA, London 2006, p. 10.

${ }^{22}$ Larry A. DiMatteo, pp. 605-06. 
tracts that take into account sustainability goals. These include government programs to incentivize the construction of energy efficient or green buildings. The criteria for earning such certifications include the use of locally sourced sustainable materials, reduction in water usage, energy efficiency, quality of indoor air, and minimization of environmental pollution. In addition, the use of products constructed with recycled materials should be encouraged. Such criteria should be included in public and private contracts. Contract clauses that require the use of sustainable processes and materials can be required in the construction of public buildings and infrastructure. In private contracts, government incentives and education on the long-term profitability obtainable through green construction is needed to persuade owners in private construction.

\section{ADVANCING SUSTAINABILITY THROUGH WARRANTY LAW}

This Part examines the problem of manufacturers' designing products to fail (planned obsolesence). Instead of producing reasonably durable products, many manufacturers' produce goods that are less durable from a state of art and design perspective. This strategy is employed to increase profits by selling repair parts and to sell new replacement products. Sustainability goals are dependent on the production of products that are durable and that can be re-used or re-cycled when they do fail. This Part examines the use of more robust warranty laws to combat the manufacturers' production of products with short lifespans.

\section{Problem of Planned Obsolesence}

The idea of planned obsolescence has been around for a while, traceable to at least the Great Depression. ${ }^{23}$ For example, the charge has been made that appliances today are not made to last, but are instead made to fail in a shorter period of time than the state of the art allows without any prohibitive increase in production costs. ${ }^{24}$ A notorious case of planned obsolesence is the 1920s "Phoebus cartel"25

${ }^{23}$ See Bernard London, Ending the depression through planned obsolescence, 1932, p. 1; Giles Slade, Made to break: technology and obsolescence in America, 2006, p. 5.

24 See Planned Obsolescence, The Economist, Mar. 23, 2009, www.economist.com/news/ 2009/03/23/planned-obsolescence; G. Slade, p. 5.

25 See, e.g., Jürgen Reuß, Cosima Dannoritzer, Kaufen für die Müllhalde: Das Prinzip der Geplanten Obsoleszenz, Orange Press, 2013, p. 13; Jana Valant, Planned Obsolescence: Exploring the Issue, 2016, available at www.europarl.europa.eu/RegData/etudes/BRIE/2016/581999/EPRS_ BRI\%282016\%29581999_EN.pdf, 23.09.2019. ("One of the last remaining examples of the old bulb, the Centennial Light Bulb, manufactured by the Shelby Electric Company and installed in 1901, still continues to function 24 hours a day in 2016."). 
or "Phoebus agreement"26 - which involved an agreement between manufacturers on limiting the lifetime of light bulbs to a maximum of 1,000 hours of operation. ${ }^{27}$ The revelation of the Phoebus cartel initiated a debate on the interrelationship between increasing profits, producing eco-friendly and sustainable goods, and consumers' interests in being able to buy goods that will last as long as technologically possible. ${ }^{28}$ More recent times have witnessed an increasing number of additional, less economic-focused reports that indicate the existence of obsolescence strategies. ${ }^{29}$ Environmental concerns linked to sustainable production and use of goods has intensified the planned obsolescence debate.

Unfortunately, private law and government regulation has been slow in responding to the problem of planned obsolesence. The only significant case in the United States involving planned obsolescence is Tatum v. Chrysler Group, ${ }^{30}$ which involved a class action suit against Chrysler in the sale of the Dodge Journey crossover vehicle. The plaintiff alleges that the brakes on the vehicle required frequent and costly repairs. Chrysler's "advertisements, which touted the Journey as safe, durable and reliable." ${ }^{31}$ Chrysler claimed that: "the brakes routinely outlasted their sales warranty, and that the advertising was not intended to create a literal representation, but was merely puffery." 32 A stronger case of misrepresentation would be available under most European advertising laws, which see such statements as factual in nature. The court rationalized that the statement of pro-

26 See, e.g., Monopolies \& Restrictive Practices, Commission's Report on the Supply of Electric Lamps, at pp. 141-142.

27 Markus Krajewski, The Great Lightbulb Conspiracy, IEEE Spectrum, 2014, https:// spectrum.ieee.org/tech-history/dawn-of-electronics/the-great-lightbulb-conspiracy, 23.09.2019.

28 See J. Valant.

29 See, e.g. Centre Européen de la Consommation \& Zentrum für Europäischen Verbraucherschutz e. V., L'Obsolescence Programmée ou les Dérives de la Société de Consommation, 2013, p. 3,www.cec-zev.eu/fileadmin/user_upload/eu-consommateurs/PDFs/publications/etudes_et_rapports/ Etude-Obsolescence.pdf; 23.09.2019; Taiwo K. Aladeojebi, "Planned Obsolescence", The International Journal of Scientific \& Engineering Research, No, 4, 2013, pp. 1504, 1505-06; Stefan Schridde, Murks? Nein Danke! Was wir tun können, damit die Dinge besser warden, 2014; Adrian Porter, Are Washing Machines Built to Fail? We Chart the Rise of the Throwaway Appliance, Which? News, 2015, www. which.co.uk/news/2015/06/are-washing-machines-built-to-fail-406177, 23.09.2019.

30 Tatum, 2011 U.S. Dist. LEXIS 32362. Another case in which planned obsolescence was discussed in dissent is not relevant to the current analysis because it involved the assessment of property; further, this case involved an unpublished opinion and under Michigan Court of Appeals Rules, has no precedential value. See Danse Corp. v. City of Madison Heights, No. 215486, 2001 Mich. App. LEXIS 1058, p. 1 (Ct. App. Mar. 23, 2001).

\footnotetext{
31 See Tatum, 2011 U.S. Dist. LEXIS 32362, p. 2.

32 Ibidem.
} 
ducts durability and reliability is not a misrepresentation by placing the failure of the braking system in the context of the automobile as a whole. Since it is a single component of many in the vehicle, then braking failure does not contradict the claim of durability and reliability. ${ }^{33}$

Unfortunately, the court granted summary judgement determining that there was not a sufficient factual record to decide the case on its merits. However, in dictum, the court addressed the issue of planned obsolescence as the basis for a claim, but dismissed the idea out of hand: "Planned obsolescence, either deliberately or accidentally engineered, is not actionable, and if the brakes outlasted their sales warranty even by a day or a mile, there would be nothing rising to the level of a design flaw for Defendants to warn of." ${ }^{34}$ Thus, the court equates planned obsolescence with the express warranty: as long as the product works properly during the period of the warranty, then any planned obsolescence that results in failures soon after the expiration of the warranty is not actionable. The court goes further by reasoning that there is no claim in products liability for defects of design since there is no such patent defect if the product lasts through the warranty period. This is an unusually narrow interpretation of products liability.

Europe has been equally slow in responding to the issue of product durability and the problem of planned obsolesence. However, more recently, the problem has taken on a higher profile and there is a trend to combat the problem. The first, indirect references are found in environmental directives and regulations that address the issue of reducing waste in general. Examples include the Waste Electrical and Electronic Equipment Directive ${ }^{35}$ and the Waste Framework Directive. ${ }^{36}$ Others, such as the Ecodesign Directive ${ }^{37}$ and the Energy Labelling

33 As to the claims of misrepresentation durability and reliability in Chrysler's advertisements, the court suggests that "to the extent that any warranty of reliability and durability could be teased from the advertising, durability and reliability may be based on multiple factors, not just one element of the car, albeit a vitally important one. Absent specific claims as to the braking system, Defendant's general advertising was puffery [hyperbole] as that is understood in the law." Ibidem, pp. 13-14.

34 Ibidem, p. 10.

35 See Directive 2002/96/EC of the European Parliament and of the Council of 27 January 2003 on the Waste Electrical and Electronic Equipment (WEEE), 2003 O.J. (L 37) 24.

36 See Directive 2008/98/EC of the European Parliament and of the Council of 19 November 2008 on Waste and Repealing Certain Directives, 2008 O.J. (L 312) 3.

37 See Directive 2009/125/EC of the European Parliament and of the Council of 21 October 2009 Establishing a Framework for the Setting of Ecodesign Requirements for Energy-Related Products, 2009 O.J. (L 285) 10. 
Directive ${ }^{38}$ are aimed to provide consumers with information on ecologically relevant information to allow for informed decision-making by buyers interested in purchasing eco-friendly products.

More importantly, warranty law has been recognized as a vehicle for combatting planned obsolesence and waste through greater product lifespans. The European Economic and Social Committee (EESC) adopted an opinion on planned obsolescence. ${ }^{39}$ The EESC referred to planned obsolescence broadly as "a form of industrial production that relies on a minimum renewal rate for its products," leading to consumer abuse. ${ }^{40}$ The committee highlighted different advantages of sustainable production, ranging from positive influences on the environment to greater economic innovation. ${ }^{41}$ With respect to guarantees (warranties), the EESC suggested an enhanced system to "curb . . . out the most flagrant cases." 42 The Committee suggested that greater sustainability could be achieved by the introduction of "a minimum operating period, during which the cost of any repairs should be borne by the producer." ${ }^{3}$

The initial work by the EU Commission and the EESC was followed by additional investigations by other European institutions and committees aimed at evaluating ways to ensure product durability and to improve the disclosure of information with respect to product lifetimes. The Influence of Lifespan Labelling on Consumers Study (2016 EESC Study) concluded that the introduction of lifespan labeling would likely have a positive effect in terms of the purchase of sustainable products. ${ }^{44}$ First, a significant number of consumers would have an interest in obtaining information on product lifespans. Second, comprehensible information would increase the sale of sustainable products. ${ }^{45}$

38 See Directive 2010/30/EU of the European Parliament and of the Council of 19 May 2010 on the Indication by Labelling and Standard Product Information of the Consumption of Energy and Other Resources by Energy-related Products, 2010 O.J. (L 153) 1, 2.

39 See generally Opinion of the European Economic and Social Committee and the Committee on "Towards More Sustainable Consumption: Industrial Product Lifetimes and Restoring Trust through Consumer Information", 2013 O.J. (CCMI 112) 1.

40 Ibidem.

41 Ibidem, pp. 5-6.

42 Ibidem, p. 1.

43 Ibidem, p. 3.

${ }^{44}$ ILLC Study: The Influence of Lifespan Labelling on Consumers, Eur. Econ. \& Soc. Comm. 2, 84 (Mar. 2016), www.eesc.europa.eu/resources/docs/16_123_duree-dutilisation-des-produits_ complet_en.pdf, 23.09.2019.

45 Ibidem, p. 2. "The results of the test show that lifespan labelling has an influence on purchasing decisions in favour of products with longer lifespans. On average, sales of products with a label showing a longer lifespan than competing products increased by $13.8 \%$." Ibidem. 


\section{Warranty Law and Product Durability}

The existing law that seems best suited for the task of increasing product durabilityis warranty law. It can be generalized that the idea behind every warranty regime is to guarantee that purchasers receive products of a quality, which they are reasonably entitled to receive. ${ }^{46}$ In cases of planned obsolescence the purchaser receives a product that is not of the quality owed under the contract (fails to meet mutually agreed quality standards) or because the product fails to perform for the reasonably expected (implied) lifetime. The premature end of a product's lifetime, if regarded as substantial in nature, should be classified as a physical defect recognizable under warranty law.

As for the question of what purchasers may reasonably expect regarding the lifespan of a product, a two-staged approach is warranted. First, groups of comparable products need to be identified and a product group benchmark of durability developed to measure acceptable durability deviations (reasonable margin of tolerance). Parameters such as the product price, product presentation, and product design influence whether a respective product reaches the threshold of the reasonable expectation of durability. Second, significant deviations from expected lifespans that go beyond an acceptable range of tolerance should result in planned obsolescence being recognized as a material defect under warranty law.

Arguably the "simplest" strategy to maximize the potential of warranty law is to introduce longer or extended warranty periods. This approach can be found, for example, in Ireland and the United Kingdom, which adopted six yearwarranty periods ${ }^{47}$ and Sweden with a three year-period. Belgium has a prescription period of ten years, ${ }^{48}$ limited to latent defects as defined by Article 1641 of the Belgian Civil Code. ${ }^{49}$ Although some of these extended warranty periods

46 This expectation may vary based upon the price charged, the state of the art in the given industry, and historical views of durability.

47 Scotland, however, provides of a five-year period.

48 Article 2262bis of the Belgian Civil Code.

49 Note, for other cases of physical defects the purchaser can "only" refer to the narrower warranty scheme of Articles 1649bis-1649octies of the Belgian Civil Code that, in principle, implemented the CSD regime. For details see European Commission, Consumer market study on the functioning of legal and commercial guarantees for consumers in the EU - Country fiche: Belgium (2015) 8 and Germany Trade \& Invest, Gewährleistungsrecht Belgien (2015) 2, available at www. gtai.de/GTAI/Navigation/DE/Trade/Recht-Zoll/Wirtschafts-und-steuerrecht/Produkte/Dienstleistungsrecht/Portal21/Laender/Belgien/Rechtsrahmen/Zivilrecht/gewaehrleistunsgrecht.html, 23.09.2019. 
were not originally directed at cases of latent defects, they should be of considerable help in attempts to regulate planned obsolescence. ${ }^{50}$

A greater impact on the problem of planned obsolescence can be seen in the revision of French law relating to latent defects - the "garantie des vices caches" (warranty for latent defects). This scheme is enshrined in Articles 1625 et seq. of the French Civil Code with a group of key provisions found in Articles 1641 to 1649. Under the basic rule of Article 1641, the seller has to warrant that goods are free from latent defects, which makes the purchased good unfit for the intended purpose or generally impairs the purchaser's reasonable expectation of usability. ${ }^{51}$ If a physical defect can be classified as a latent defect in the meaning of Article 1641 , purchasers may be in a better position to win a claim of planned obsolescence.

Article 7:23 of the Dutch Civil Code (Burgerlijk Wetboek) provide a purchaser-friendly rule. Studies point out that the Dutch system is particularly suitable to cover incidents of shortened product lifetimes, because it puts a greater emphasis on the importance of lifespans. ${ }^{52}$ Products that do not reach a reasonably expectable lifetime are considered to be defective. The combination of the flexible warranty claim prescription period and the recognition of shortened product life spans as a defect benefits purchasers in cases of planned obsolescence. The European Consumer Centres Network (ECC-Net) characterizes the Finnish system as incorporating a "reasonably expectable lifespan" assessment tool, under which the Finnish Consumer Disputes Board has the competence to issue (nonbinding) lifespan standard ranges for different product categories. ${ }^{53}$ If a product falls significantly short of the applicable target, a warranty relevant (durability) defect, as in the case of the Netherlands, is presumed. It has to be added that the

50 This understanding rests on the assumption that respective cases of not reaching reasonably expectable product lifetimes constitute warranty relevant physical defects.

51 Article 1641 of the French Civil Code: "A seller is bound to a warranty on account of the latent defects of the thing sold which render it unfit for the use for which it was intended, or which so impair that use that the buyer would not have acquired it, or would only have given a lesser price for it, had he known of them". Translation by Georges Rouhette and Anne RouhetteBerton available at www.legifrance.gouv.fr/content/download/1950/13681/version/3/file/Code_22.pdf, 23.09.2019.

52 See, e.g. ECC-Net, Commercial Warranties 17; European Commission, Consumer market study on the functioning of legal and commercial guarantees for consumers in the EU - Final report (2015) 22.

53 ECC-Net, Commercial Warranties 17. 
possibility to file a warranty claim itself lapses after three years from the objective detectability of the defect. ${ }^{54}$

\section{PLANNED OBSOLESENCE FROM A WARRANTY LAW PERSPECTIVE}

This Part offers a number of law reform recommendations that provide means to address the problem of product durability through changes in warranty law. The recommendations include: (1) extending limitation periods to accommodate delayed cases of planned obsolescence; (2) recognizing planned obsolesence as a latent defect under warranty law by introducing tailor-made period designs; (3) mandatory durability or lifespan disclosure requirements; (4) enactment of an implied warranty of durability; (5) prioritizing the remedy of repair over that of replacement, and (6) recognition of a consumer's right to repair.

\section{Mandatory Product Warranty Periods}

The problem presented by planned obsolescence is that the shortened lifespan of the product often appears after the running of the statute of limitations (limitation periods). This is because planned obsolescence is mostly latent in nature. It also because statute of limitations can be relatively short in length. ${ }^{55}$ One approach is to simply extend the statutory warranty period based upon some expectation of product durability. Another approach is to recognize lack of durability as a latent defect in which the limitation period begins at the time of discovery. Planned obsolescence warranty relevant defects are constituted if products fail to perform for the reasonably expectable lifetime of a product. In this context, planned obsolescence should be recognized as a latent defect in the sense that they are not visible at the time of delivery, but manifest later, in many cases significantly later. An alternative approach, discussed in the next section, is to recognize a new warranty-the warranty of durability, which would not be disclaimable in a contract.

The manufacturer should be offered two defenses-state of art and disclosure of durability. Tort (delict) or products liability law recognizes the state of the art defense. There are two variations of the state of the defense-one asser-

54 This solution follows the general prescription rule for contract based claims enshrined in Articles 5 and 7 of the Finnish Act on limitations on debts. Finnish law does not know a specific rule for warranty claims.

55 The law of Pennsylvania limitation periods provides for two years for injury to person or property related to defects of products. Penn. Stat. Title $42 \S 5524$. 
ting that the manufacturer followed "industry-wide standards to which the [manufacturer] had conformed" and the other arguing that the manufacturer could not have produced a safer durable product "within the current limits of scientific knowledge." 56 The start of art defense is most useful in the case of design defects. Planned obsolescence is often an outcome of a poor design, as well as the use of poor manufacturing materials or component parts.

The state of the art defense should be modified in cases of planned obsolescence. First, industry standards may allow for planned obsolescence, since the same incentive structure (creating a market for repair parts and increasing future sales of products to replace obsolescent products) often persist throughout the major manufacturers in a given industry. Second, the use of the current limits of scientific knowledge standard is a better fit for safety defects and not issues of durability. A more appropriate affirmative defense would require the manufacturer to show that it used an appropriate design and materials that would ensure a durable product (expected lifespan of a reasonable consumer). Cost constraints are often prohibitive in obtaining optimal durability. Thus, the standard is not absolute durability but reasonable durability.

Disclosing information regarding the durability of products can be considered as part of the solution. The idea of durability diverges between manufacturers and buyers mostly due to informational asymmetry. The manufacturer retains inside information of the durability of a product as engineered and produced. The buyer, working without such information, often expects that the product will function beyond the period of the manufacturer's planned obsolescence. In order to encourage manufacturers to disclose information on products' likely lifespans, a disclosure of durability defense should be recognized. Providing buyers with information on expected product lifetimes increases transparency and facilitates informed decision-making.

\section{Implied Warranty of Durability}

Previously, it was argued that planned obsolescence under normal circumstances could be regarded as part of warranty law. Usually parties do not explicitly integrate the expected lifetime in the contract. But the durability notion is widely considered to be an expression of implied quality standards at least in consumer sale (B2C) situations. Some jurisdictions-Armenia, Australia, the Canadian provinces of British Columbia and Quebec, Hong Kong, Mongolia and South Africa-

56 James T. Murray, Jr., "The State of the Art of Defense in Strict Liability", Marquette Law Review, Vol. 57, 1974, pp. 649, 651, 652. 
go one step further and explicitly list statutory durability parameters as warranty law relevant quality criterion. The laws correctly classify durability as within the scope of warranty law, by applying reasonable expected lifetime standards. The durability standards are recognized based on product group durability benchmarks that indicate reasonably expected product group lifetimes. If the lifespan of a product is not within an acceptable range of tolerance from such standards, durability shortfalls may result in a claim of breach of warranty.

Identifying product group benchmarks and defining acceptable ranges of deviation is admittedly a difficult task. But the Finnish example shows that it is possible. As discussed earlier, the Finnish Consumer Disputes Board has the competence to issue lifespan standard ranges for different product categories. If a product falls significantly short of the applicable target, a warranty relevant defect is assumed. The advantage of such an approach can be seen in its objectivity and comprehensiveness. Standard ranges set minimum durability limits. At the same time, however, they allow producers to design their products quite "autonomously" in the sense that falling short of the average durability of comparable products does not necessarily constitute a warranty defect. Defects are assumed only if the durability deviation is considered substantial and unacceptable.

\section{Manufacturer's Duty to Repair}

In order to prevent waste, the manufacturer-seller should be required to make a prompt repair of faulty products. Only after a good faith effort to make repair should replacement be used as a remedy. Most countries provide a menu of remedies or cascade remedial schemes. Repair and replacement enjoy priority over secondary remedies, in most cases over price reduction and rescission (termination). From an environmental perspective, the consequences of repair and replacement differ widely. The negative impacts of replacement on the environment outweigh those of repair. This is due to the fact that replacement creates considerably greater waste than does repair. Considering the differentiation in environmental or sustainability costs between repair and replacement, remedial schemes found in the United States and other countries should be reformed to prioritize the repair over replacement remedy.

Currently, the law at the EU level-Article 3(3) of the Consumer Sales Directive (CSD), and non-EU jurisdictions that follow the CSD, give the choice to the buyer to receive repair or replacement. It can be argued 
that this is an improvement, because consumer choice overcomes the bargaining power disparities that previously allocated the choice to the seller. Under the American scheme the choice to repair or replace lies with the seller.

From an environmental perspective either solution (leaving the choice to the buyer or the seller) might not be the best possible solution. Environmentally friendly purchasers and sellers would be inclined to choose a resource-efficient way of bringing the defective good into contractual conformity by opting for repair instead of replacement. However, less environmentally friendly purchasers and sellers are likely to choose replacement despite a product being repairable. A better or more sustainable model would be to take the choice away from either party by obligating the seller to promptly repair. The content of such a model would include the use of replacement when repair is cost prohibitive, replacement after a maximum number of repairs have been reached, and a purchaser right to a temporary substitute product in cases of unduly long periods of repair.

In sum, even if it may be easier to replace a product, repair should be made the preferred remedy unless repair proves to be cost prohibitive or otherwise unreasonable. ${ }^{57}$ Additionally, the law, especially where the product has been heavily used, could allow the seller to replace with refurbished goods. This would a more environmentally friendly form of replacement by reducing as waste (through reuse) and would increase the incentive to recycle obsolescent products.

\section{Buyer's Right to Self-Repair}

There are two distinct movements whose goal is to provide consumers a right to repair. One is embedded in consumer protection rationales. Consumers should be allowed to repair their own products rather than be forced to seek more expensive alternatives (higher costs of repair in manufacturer-certified repair shops or to purchase a new product). The parallel movement relates to sustainability goals of governments and international instruments aimed at reducing waste and pollution in response to climate change.

57 Sustainability goals also require in cases of replacement that the manufacturer also be obligated to mine the goods being replaced for reusable materials. The idea of recognizing post-replacement obligations of a manufacturer has been suggested previously: "Extended Producer Responsibility (EPR) is a policy that shifts responsibility for collection and recycling of post-consumer goods from governments to producers." Conrad B. MacKerron, "Moving toward to Sustainable Consumption in Electronics Design, Production, and Recycling", The Utah Environmental Law Review, Vol. 31, 2011, p. 117. 
In the area of consumer protection there is now a model law ${ }^{58}$ recognizing a consumer's right to self-repair and the reciprocal duties of manufacturers. The four parts of the model law include: "(1) mandating disclosure of information that will allow repairs; (2) mandating the availability of parts and tools to facilitate repairs; (3) mandating disclosure of information to allow security protections to be reset; and (4) forbidding any contracting-around of such provisions in [contract] terms between authorized repair providers and the original equipment manufacturers." 59 Examples of designs that make self-repair difficult include affixed or glued batteries in electronic products and the Apple screw that prevents opening and repairing of Apple products with ordinary types of screwdrivers. In order to make self-repair possible, companies should be required to make available the manuals needed to effectuate self-repair, along with maintaining an inventory of repair parts.

From the perspective of warranty law, the right to self-repair has is relevant. The key point of intersection or conflict relates to classifying the lifetime-ending irreparability of a product as a planned obsolescence defect. As discussed earlier, planned obsolescence refers to cases in which the usability of a product is prematurely ended (as the result of a manufacturer's strategy). The question arises whether cases of irreparability fall under this definition. A parallel can be drawn from defining planned obsolescence as a latent defect. The latent defect is described as a product's failure to perform for a reasonably expected lifetime. Irreparability can be classified as planned obsolescence if it is, at least partially, the reason why a product did not meet expectable lifetime standards. However, irreparability itself cannot be regarded as warranty law relevant. Under warranty law, a product's failure to meet its expected product lifetime relates to the end of usability regardless of the question whether the defective product can be repaired or not. Hence, irreparability can be evidence of planned obsolescence, but in itself would not be a violation of current warranty law.

The question whether or not products are repairable could be treated autonomously in a warranty law context. This is particularly the case if it can reasonably be expected that a product is repairable. This is a separate issue than that of planned obsolescence. In this scenario it is not so much a question of defect due to durability than a question of irreparability. However, the simplest way to recognizing the right to self-repair is to incorporate it into warranty law. In sum,

58 See Repair. Org., Legislative Template, https://repair.org/s/Right-to-repair-Model-statelaw-7-24-18.docx, 9.01.2019.

59 Leah Chan Grinvald, Ofer Tur-Sinai, "Intellectual Property Law and the Right to Repair", Suffolk University, Legal Research paper No. 19-4, p. 15, available at http://ssrn.com/abstract $=3317623,09.02 .2019$. 
warranty law should be expanded to include protection against actual defects and a separate duty of reparability.

\section{Circular Economy and Servitization}

Ultimately, sustainability depends on the efficient use and re-use of sources and materials. A circular economy focuses on the dematerialization of the economy by the diminishment of dependency on scarce resources. This process involves numerous techniques and approaches to material use and the production of waste. Examples include the changing of perspectives from replacing the purchase of products with the sharing of products. The share economy allows people to share their homes (Airbnb) and to share rides (Uber). The next generation of sustainability products would involve the conversion from buying basic goods to sharing or leasing of goods. "Servitization" seeks to replace ownership of things with the leasing or sharing of things. ${ }^{60}$ This would entail converting purchase contracts to service contracts. For example Phillips (lighting manufacturer) offers a program that instead of buying their light bulbs a company may enter into a service contract in which Phillips maintains, repairs, and replaces the company's lighting system.

Servitization incentivizes a manufacturing to make longer lasting products. When selling light bulbs a company is incentivized to limit their lifespans so as to generate additional sales in the future. In a service contract scenario, the incentives are reversed in that the company wants to reduce the costs of servicing by producing longer lasting bulbs. Another, type of dematerializing is to replace the common warranty of repair and replacement with a repair warranty. One suggestion would remove the buyer's right to demand repair or replacement and substitute it with a seller's right to repair. To bolster the ability to repair goods, law should require that the seller and its distributors maintain an adequate supply of repair parts for a reasonable period of time.

\section{CONCLUSION}

Many consumers are now motivated to seek out goods that were produced using environmentally friendly processes and that advance the goals of sustainability. For example, the EU Ecolabel criteria take a lifecycle approach that assesses he production cycle from the extraction and use of natural resources, the produc-

${ }^{60}$ Much of the material presented here was borrowed by a talk given by Prof. Dr. Evelyne Terryn, "Consumer Protection and Circular Economy," Research European Private Law Conference, Osnabruck, Germany, October 17, 2018. 
tion process, the products lifecycle, the use of recycling of reusable materials, and methods to use any waste in a productive way. ${ }^{61}$ Ultimately, sustainability depends on the efficient use and re-use of sources and materials. In addition, longer lasting products reduce the need for natural resources and decreases waste. From a consumer perspective, many products do not last as long as a purchaser may have reasonably expected. In recent years, environmental concerns linked to sustainable production and use of goods has intensified the planned obsolescence debate. Increasing the durability or functionality of products is a core sustainability goal.

This Report makes the argument that contract law and contracts can be used creatively to advances sustainability goals, whether in the private or public sectors. It reviews different types of contracts, such as government-to-government, government procurement, and private contracts. The Report also discusses the use of green building contracts. It recommends the greater use of sustainability clauses in public and private contracts. In the area of contract law it discusses the creation of an implied warranty of sustainability that promotes the sustainable production of goods and the recognition of planned obsolesence as a latent defect in warranty law to encourage the production of durable products.

Prof. dr LARRY A. DIMATTEO

Profesor na Levin College of Law

Univerzitet na Floridi

\section{PRAVO NA ČISTO OKRUŽENJE: ULOGA UGOVORA I UGOVORNOG PRAVA}

Rezime

U radu se analizira značaj ugovora i ugovornog prava za ostvarivanje ciljeva održivosti. Autor izlaže problem planiranog veka trajanja u slučaju kad prema nameri proizvođača proizvod ima kraći vek trajanja. Posebna pažnja posvećena je pitanju primene i izvršivosti klauzula o održivosti ugovora, sa stanovišta opštih pravila ugovornog prava. Uloga ugovora u unapređenju održivosti u radu je analizirana na različitim nivoima: u ugovorima između dve države - bilateralnim investicionim sporazumima, u javno-privatnim ugovorima (javna nabavka) i privatnim zelenim ugovorima stimulisanih javnom politikom i strategijom. U zaključnim delovima rada predložena su rešenja u pogledu problema planiranog veka trajanja, pri čemu se pravo po osnovu garancije ističe kao optimalno sredstvo zaštite potrošača.

Ključne reči: bilateralni investicioni sporazumi (BIT), cirkularna ekonomija, obaveza popravke, javna nabavka, zeleni ugovor, podrazumevana garancija trajnosti, planiran vek trajanja, pravo na (samo)popravku, održivost, pravo potrošača po osnovu garancije

61 See European Commission, "Ecolabel for Consumers", available at http://ec.europa.eu/environment/ecolabel/eu-ecolabel-for-consumers.html, 23.09.2019. 
Bibliography

Cafaggi Fabrizio, "Regulation through Contracts: Supply Chain Contracting and Sustainability Standards," European Review of Contract Law, Vol. 12: 1, 2016.

Colins Hugh, Regulating Contracts (Oxford: Oxford University Press), (1999).

Czamezki Jason, “The Future of Food Eco-Labeling," Stanford Environmental Law Journal, 30: 3, 7, 2011.

DiMatteo Larry \& Wrbka Stefan, "Planned Obsolescence and Consumer Protection: The Unregulated Extended Warranty and Service Contract Industry," Cornell Journal of Law \& Public Policy, Vol. 28, 2019.

Edman Asa \& Nohrstedt Peter, "No Socially Responsible Public Procurement without Monitoring the Contract Conditions," European Procurement \& Public Private Partnership Law Review, Vol. 12, 2017.

European Commission, Consumer market study on the functioning of legal and commercial guarantees for consumers in the EU - Final report, 2015.

European Economic And Social Committee, Towards more sustainable consumption: industrial product lifetimes and restoring trust through consumer information, 2013.

European Economic And Social Committee, "ILLC study - The Influence of Lifespan Labelling on Consumers: Executive summary - March 2016”, 2016.

Fisher Eleanor, "The Power of Purchase: Addressing Sustainability through Public Procurement," 8 European Procurement \& Public Private Partnership Law Review, Vol. 2, 2013.

Griggs David, "Sustainable Development Goals for People and Planet," Nature Vol. 495, 2013.

Hottinger Christine, "For an Implied Warranty of Sustainability: Come Mr. Tallyman, Tally My Banana's Environmental Impact," Georgetown International Environmental Law Review 26: 303, 2014.

Mackerron Conrad B., "Moving toward to Sustainable Consumption in Electronics Design, Production, and Recycling," Utah Environmental Law Review 31: 117, 2011.

Mccall-Smith Kasey \& Rühmkorf, Andreas, "From international law to national law: The opportunities and limits of contractual CSR supply chain governance," University of Edinburgh Research Paper No. 28/13, at p 13, <htpps://ssrn.com/abstract=3253149> (last access October 30, 2018).

McCall-Smith Kasey \& Rühmkorf Andreas, "Sustainable global supply chains: From Transparency to due diligence," University of Edinburgh Research Paper No. 2018/31 $<$ https://papers.ssrn.com/sol3/papers.cfm?abstract_id=3253152> (last access October 30, 2018).

Mitkidis K. Peterkova, Sustainability Clauses in International Business Contracts (Netherlands: Eleven International Publishing), 2015. 
Slade Giles, Made to Break - Technology and Obsolescence in America, 2006.

Vandevelde Kenneth J., “A Brief History of International Investment Agreements," University of California Davis Journal International \& Policy, Vol. 12, 2005.

Vytopil Louise, Contractual Control in the Supply Chain, Netherlands: Eleven International Publishing, 2015.

Wrbka Stefan \& DiMatteo Larry A., "Comparative Warranty Law: Case of Planned Obsolesence," University of Pennsylvania Journal of Business Law, Vol. 21, 2019.

Wrbka Stefan, "Warranty law in cases of planned obsolescence - The Austrian situation" European Consumer \& Marketing Law 67, 2017.

Yu Peter K., "Intellectual Property, Human Rights, and Methodological Reflections," Texas A \& M School of Law Research Paper No. 18-36 <https://ssrn.com/abstract $=3247346>$ (last accessed 8 October 2018).

Article history

Received: 19.09.2019.

Accepted: 15.10.2019. 